\title{
Home Weaving in Southeast Iowa, 1833-1870
}

\section{Loris Connolly and Agatha Huepenbecker}

ROMANTICIZED accounts of frontier life depict home textile production as one of the necessary burdens of self-sufficient pioneers, specifically the burden of pioneer women. A family of four in the Midwest of 1850 required, for its annual wardrobe, "a minimum of forty yards of cloth, or at least two full weeks at the wheel and loom for an experienced housewife. This work was, of course, spread throughout the available time, and one could expect to find women spinning or weaving almost any time of the day, at every season of the year." Women's work was, indeed, never done. Many Iowa histories repeat the judgment that hand weaving, among women's other chores, was "tedious." Women undertook it only because "storeclothes were virtually unknown even if there had been money to buy them." Without access to commercial goods, Iowa settlers begrudgingly produced all of their own outer and under garments. As soon as manufactured fabrics and clothing became available, grateful Iowa women supposedly abandoned the drudgery of spinning and weaving for what they could buy in town. ${ }^{1}$

The authors developed this article from Loris Connolly's master's thesis, "Home Weaving, Professional Weaving, and Textile Mills in Southeast Iowa, 1833-1870" (Ames: Iowa State University, 1982). They acknowledge the Home Economics Graduate Student Research Fund, College of Home Economics, Iowa State University for its support of the research for that thesis.

1. Quotations from John M. Faragher, Women and Men on the Overland Trail (New Haven, 1979), 55; William J. Petersen, The Story of lowa, 4 vols. (New York, 1952), 1:362, 364. See also Clarence Aurner, lowa Stories (Iowa City, 1918), 80, 86-89; George Duffield, Memories of Frontier Iowa (Des Moines, 1906), 13, 24-25; Ruth Gallaher, "The Iowa Pioneers," Palimpsest 8 (January 
Although most Iowa historians have assumed that the primary motivation for hand weaving was the inaccessibility of commercial goods, few have presented evidence to substantiate this conclusion. Most historical accounts also do not describe the tools, processes, and textile products that were part of household manufacture. Most descriptions of hand weaving and textile products in nineteenth-century Iowa are elusive in terms of the actual time period covered. Thus we commonly associate hand-woven fabrics and "homespun" clothes with "the frontier," "early days," or "pioneer times." Often spinning wheels and looms appear only in stereotypical descriptions of pioneer log cabins. ${ }^{2}$

Yet Iowans continued to weave their own cloth despite access to commercial goods, when they no longer lived in a frontier area or log cabin, and for reasons apart from necessity. While diaries, letters, and reminiscences of weavers or firsthand descriptions of home-woven products are rare, the available evidence shows that hand weavers and spinners were among the earliest settlers of southeast Iowa in the 1830s. The presence of the necessary raw materials, looms, and other equipment, and a variety of community services that fostered home weaving, is apparent in historical documentation up to the 1870 s and beyond. Furthermore, surveys of early Iowa newspapers show that commercial cloth and ready-made clothing were available in eastern regions of the state as early as 1836. If Iowans wove their own fabrics regardless of the availability of manufactured goods, the task must not have been purely a burden of pioneer existence.

Hand-woven textiles made in nineteenth-century southeast Iowa included hand-spun linen and wool yarns along with some machine-spun cotton. Home weavers produced flannel, jean, and other fabrics for clothing such as everyday pants and

1927), 1-23; Glenda Riley, "Women Pioneers in Iowa," Palimpsest 57 (March/ April 1976), 34-53; George F. Robeson, "Hard Times in Early Iowa," Palimpsest 5 (May 1924), 157-171.

2. Aurner, Iowa Stories; Susan I. Dubell, "Rural Pioneering," Palimpsest 22 (December 1931), 225-239; Gallaher, "Iowa Pioneers," 21-23; Petersen, Story of Iowa, 361-364; Mildred J. Sharp, "Early Cabins in Iowa," Palimpsest 2 (January 1921), 16-29; Henry C. Taylor, Tarplewick: A Century of Iowa Farming (Ames, 1970), 13, 28-29. 
dresses, as well as for tablecloths, sheets, blankets, coverlets, carpets, and curtains. They commonly used four-harness barn frame looms for this manufacture. Museum examples and firsthand written accounts are not extensive enough to identify which household textiles or types of clothing Iowa weavers most commonly produced from the 1830 s to 1870 . The predominance of overshot coverlets in public and private collections probably results from their special treatment as decorative textiles rather than as objects of daily use. But extant textiles, tools, and documentation do reveal preferences for particular raw materials, techniques, and tools. This evidence in turn contributes to one aspect of Iowa's technological, social, and commercial history. ${ }^{3}$

Iowa weavers used a variety of raw materials for cloth

3. The authors used the following public sources of material artifacts in research for this study. Private collections included the Buchanan collection, Ames; Cleveland collection, Jefferson; Davidson collection, Stanwood; Frymoyer collection, Wilton; Gobble collection, Fairfield; Larson collection, Swedesburg; Lonsdale collection, Dale City; Lyons collection, Fairfield; Meek collection, Bonaparte; Miller collection, Des Moines; Satterly collection, Farmington; and Taylor collection, Fairfield. All collections are in Iowa unless otherwise specified.

Apple Trees Museum,

Des Moines County Historical Society

Art Institute of Chicago

Aunty Green Hotel Museum

Davis County Museum

Ericson Public Library and Museum

Fairfield Public Library Museum

Grout Museum of History and Science

Iowa Mennonite Museum and Archives

lowa State Historical Department

Libraries, Museum, and State Archives

Iowa State University Library

Jackson County Historical Museum

Jefferson Historical Museum

Jonathan Clark Conger House

Lewelling Quaker House

The Looms

Mediapolis Public Library

Museum of International Folk Art

Nelson Pioneer Farm and Crafts Museum

Pioneer Historical Society Museum

Putman Museum

Van Buren County Museum

Wayne County Historical Society Museum

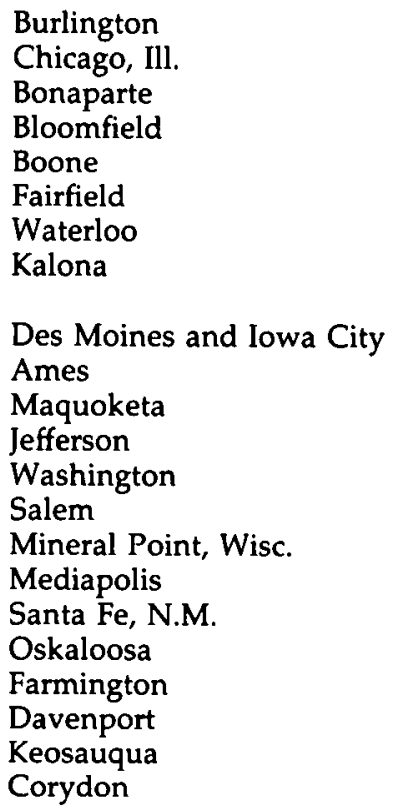


production. The fiber most frequently mentioned in historical accounts is wool. According to federal and state censuses, settlers were raising sheep for wool by 1840 in nine of the sixteen southeast Iowa counties considered. There is evidence of sheep raising, and of washing, picking, carding, spinning, and weaving wool, among southeast Iowa settlers from 1839 through 1870. The diary of an early Iowa settler, Kitturah Penton Belknap, provides descriptions of the beginning processes required to prepare wool for hand weaving. Born in Ohio in 1820, Belknap came to Van Buren County, Iowa, in 1839, two weeks after her marriage. She and her husband George were embarking on a series of trips westward. ${ }^{4}$

In May of 1842, Kitturah Belknap described the neighborhood's construction of a sheep pen on the Des Moines River. When it was ready, men drove their sheep into the pen and then took them out one at a time into the river "where they could not touch bottom with their feet." The men then would hold the sheep's "heads out of the water with one hand and with the other rub and souse them up and down till the water looked clean when they squeezed it out of the wool." When they had completed washing one owner's flock the men "sent the boys home with them and put them in a little clean pasture to dry." When done the men "all took their dinner and had a regular picnic." Edna Ollinger similarly wrote that in the spring, in Keokuk County, her grandmother's neighbors came together to drive sheep into a pond or a large body of water to wash them. Then they "bound the sheep" to shear the wool. This was in the 1860s. Kitturah Belknap continued her 1842 description in June, a month after the washing, when it was her turn to process the sheared wool.

4. John A. Hull, 1836-1880 Census of Iowa for 1880 (Des Moines, 1883). Sixteen southeast lowa counties-Cedar, Davis, Des Moines, Henry, Iowa, Jefferson, Johnson, Keokuk, Lee, Louisa, Mahaska, Muscatine, Scott, Van Buren, Wapello, and Washington-were the focus of this research as handwoven textiles and related tools exist in the greatest variety and numbers within that area. Much of Iowa's settlement began in the southeast, and so much of Iowa's culture is slightly older there. For accounts of sheep raising and wool processing see Glenda Riley, ed., "Family Life on the Frontier: The Diary of Kitturah Penton Belknap," Annals of lowa 44 (Summer 1977). 
The men are back in the corn except the sheepshearers. The sheep will be sheared this week, then the wool will lay out a few days to get the sheep smell off, then my work will begin. I'm the first one to get at the wool (sixty-five fleeces). Will sort it over, take off the poor short wool and put it by to card by hand for comforts. Then will sort out the finest for flannels and the coarser for jeans for the men's wear. I find the wool very nice and white, but I do hate to sit down alone to pick wool so I will invite about a dozen old ladies in and in a day they will do it all up. ${ }^{5}$

After cleaning and picking the wool, it was necessary to card it, or align the fibers in a parallel arrangement, prior to spinning it into yarn. With the wool cards and spinning wheels frequently seen in Iowa museums and collections, weavers produced yarn for a variety of end products. While they used some of this hand-spun yarn in woven textiles, women also carded and spun wool for knitting yarn in Iowa homes well into the twentieth century. Thus the existence of so many cards and spinning wheels in museums is not necessarily evidence of woven textile production in the nineteenth century. The notion that home weavers in Iowa controlled all steps of cloth production from raw material to finished product is popular, both in published histories and in labels attached to home-woven textiles in personal collections and museums. Yet as early as 1839 carding one's own wool by hand was not always necessary, as carding mills in southeast lowa had largely taken over the process. Hand weavers probably welcomed and took advantage of these businesses. ${ }^{6}$

Carding mills processed local wool with power-driven carding machines, which were much faster than hand cards. The power came either from a water-driven wheel or from steam. Robert Latta, in Reminiscences of Pioneer Life, described work

5. Riley, ibid., 40; Edna Ollinger, "The Story of My Grandmother," MS, 1923, Iowa State Historical Department (hereafter, ISHD), Iowa City. The Ollinger piece is from a collection of accounts with the same title, all of which were entries in an essay contest.

6. For examples of the historical belief that lowans carded all of their own wool see B. E. Bengtson, Pen Pictures of Pioneers: Biographical Sketches (Holdrege, Neb., 1926), 1:24; Cyrenus Cole, The History of the People of Iowa (Cedar Rapids, 1921), 247-248; Dubell, "Rural Pioneering"; Petersen, Story of Iowa, 361, 364; Susan F. Welty, A Fair Field (Detroit, 1968), 48-49. 
in a carding mill in Wapello, the county seat of Louisa County, when that was "a city of five or six cabins." A carder's job "was to spread the wool evenly on a table over which an endless apron revolved, and sprinkle it with melted grease; the moving apron carried the wool within reach of the teeth on the revolving cards, and it came out on the other side of the machine in rolls, ready for the spinning wheel." Latta also recalled that settlers would come from fifty miles around the mill, "bringing their own and their neighbors' wool, pinned with thorns in old sheets and blankets, and fetching along the required amount of grease in old crocks and coffee-pots. A record was kept of each bundle, and a time set to return for the rolls." Thus customers received the same wool that they brought to the mill. ${ }^{7}$

As early as 1839 , Kitturah Belknap's picked wool "came from the carding machine in nice rolls ready to spin." The end product of carding mills-rolls of wool fibers free from knots and burs-was more uniform and consistent than that which hand cards could produce. Wool rolls were commonly onehalf inch in diameter and their length depended on the width of the carding surface on the machine used. Purchasing machine-carded wool rolls saved time for hand weavers as they no longer needed to piece together shorter rolls of handcarded wool during spinning. ${ }^{8}$

Other accounts mention lowa spinners and weavers sending raw wool to carders, carding machines, or woolen mills to be made into "rolls," through the 1860s. In addition, directories and censuses list southeast Iowa carding businesses. An 1846 directory of businesses in Iowa's major towns listed two carders in Jefferson County and one in Johnson County. Census returns indicated that thirty-one professional carders were working in 1850 and twenty-five in 1856, all within a sixteen-county area in southeast Iowa. These carders may have been carding wool rolls for home weavers or for woolen mills in the area at the time. By 1860, the industry census for southeast Iowa counties listed seven carding mills which offered wool rolls for sale

7. Robert R. Latta, Reminiscences of Pioneer Life (Kansas City, 1912), 9.

8. Riley, "Family Life," 41; Arlington Mills, 1865-1912 (Norwood, Mass., 1925). 
at an average of forty cents per pound. In 1870, five carding mills offered wool rolls at an average of forty-five cents per pound while three textile mills also listed wool rolls among their products and sold them at an average of fifty-five cents per pound. Thus, by 1870 , carded raw wool still found some market among home textile producers. The mills that offered carded wool as a service in 1860 and 1870 were in the counties of Cedar, Davis, Henry, Jefferson, Keokuk, Mahaska, Van Buren, and Wapello. ${ }^{9}$

The peak number of carders who offered carded wool for home weavers or spinners probably occurred in 1850 . The federal census of that year included a footnote about the number of males who some of the "leading interests" in Iowa employed at that time. This information included all establishments producing over five-hundred dollars worth of materials per year. Carding and fulling mills, with fifty-three employees, ranked fifth in the state in total number of men employed. Only saw mills, grist mills, slaughterhouses, and brickmaking establishments exceeded carding and fulling mills in numbers of employees in 1850 Iowa. ${ }^{10}$

Carding mills and carders in southeast Iowa lightened the load of home production. When these businesses accepted barter as well as cash, their carding services were within the reach of almost any weaver. The Richmond and Shaw mill on

9. For references to professional carders or machine carding see Bengtson, Pen Pictures, 24; Thomas J. Hamilton, "History of the Hamiltons," MS, no date, in possession of Julie Emerson, Ottumwa; Latta, Reminiscences, 9; Ardith K. Melloh, "Life in Early New Sweden, Iowa," Swedish Pioneer Historical Quarterly 31 (April 1981), 124-146; Margaret E. Murray, "Memoir of the William Archer Family," Annals of Iowa 39 (Summer 1968), 357-371; Ollinger, "Story of My Grandmother"; George Stephenson, ed., "Typical American Letters," Swedish Historical Society of America Yearbook 7 (1921-22), 53-97; Taylor, Tarplewick, 13; Frances Vanderwort, "The Story of My Grandmother," MS, 1923, ISHD, Iowa City; John B. Newhall, A Glimpse of Iowa in 1846 (Iowa City, 1846, 1957), 88, 92. For statistical information Connolly surveyed U.S. Bureau of the Census, unpublished original census returns for Iowa counties in 1850, Government Publications, Iowa State University Library, Ames; Census Board, The Census Returns of the Different Counties of the State of Iowa for 1856 (Iowa City, 1857); U.S. Bureau of the Census, unpublished original census returns for Iowa industries in 1860 and 1870, Newspaper and Census Library, ISHD, Des Moines.

10. U.S. Bureau of the Census, The Seventh Census of the United States, 1850 (Washington, D.C., 1853), 954. 
the English River in Washington County advertised in an 1854 issue of Iowa City's lowa Standard: "Liberal terms for ready pay. Cash, wheat, wool, dry hides, and beeswax will be received in payment for carding. One pound of grease should accompany every seven pounds of wool." Another carder, James Hodges, operated a wool carding machine in 1845 on the Iowa River, one mile above Iowa City. Hodges advertised in the Iowa Standard that he would accept as payment for carding the same goods as Richmond and Shaw plus bacon, flaxseed, tallow, beans, and goose feathers. Purportedly Hodges's new machinery could make ninety rolls per minute or card 150 pounds of wool in twelve hours. He wanted clean wool free of all burs and required one pound of grease to accompany six or seven pounds of wool. He also promised that "if it is not well done, he will charge nothing for carding. Almost any kind of produce but promises will be taken payment for carding." An 1843 advertisement in the Davenport Gazette for John J. Tomlinson's carding and textile mill in Cedar County simply stated the mutually beneficial arrangement between home weavers and carding mills: "The Nelson Factory encourages home manufacture." 11

Once back from the carders, wool was ready for spinning and weaving. Kitturah Belknap wrote that she could spin "two skeins a day" while Mary Caplinger's grandmother in Lee County spun "enough yarn in a day to weave a yard and half of goods." Once spun, the weaver might have woven the wool yarn into an all-wool cloth such as flannel, sheets, or blankets or combined it with yarns of other fibers to produce nineteenth-century fabric blends: linsey-woolsey and jean. Kitturah Belknap's diary and Mary Stephenson's letters provide rare written descriptions of wool cloth handwoven in southeast Iowa. In July of 1842, Belknap made a new flannel dress of a small blue and red plaid. In August of 1864, Mary Stephenson wrote from New Sweden, Iowa to her family still in Sweden: "We sheared six sheep. I have twenty-four pounds of wool. I have begun to spin, and I intend to weave thirty yards of cloth warped with wool." Stephenson wrote in November of 1867

11. Iowa Standard, 9 July 1845, 10 May 1854; Davenport Gazette, 24 August 1843. 
that she had "also woven twenty-two yards of small checked blue and red woolen cloth for every-day wear. We buy cloth for better wear, instead of weaving it ourselves." She had also "woven thirteen yards of dotted blue and red woolen cloth for bed-clothes." In January of 1869, Stephenson wrote: "This year I have woven nearly ninety yards of cloth, nearly all wool." Her dotted fabric may have been like the red and brown birdseye twill cloth that her sister, Johanna Larson, wove. Larson, also a Swedish immigrant, wove in Henry County from 1869 to 1911, and her grandson's family has preserved some of her work. ${ }^{12}$

Nineteenth-century hand-woven clothing, like any garments made prior to 1870 , is rare in lowa collections. Handwoven clothing was typically work clothing which people wore out and did not feel as inclined to preserve as they did their "Sunday best." The Nelson Pioneer Farm near Oskaloosa in Mahaska County has several leather-work vests with what appears to be hand-woven wool lining. The cloth is plain weave and natural wool color. The Grout Museum of History and Science in Waterloo has a dress labeled as woven in 1850. This dress is the only extant, documented piece of handwoven wool clothing known in Iowa. The dress consists of a red and black or dark brown checked fabric. The appearance of the selvage edges in the seams and the irregularity of the yarns, possibly hand spun, mark this as a likely example of an Iowa weaver's wool garment.

The Iowa State Agricultural Society's reports and proceedings offer an additional resource for lists of hand-woven fabrics. The society held an annual fair and cataloged those fabrics which participants entered under the fair classes of "domestic

12. Riley, "Family Life," 41; Mary Eliz Caplinger, "The Story of My Grandmother," MS, 1923, ISHD, Iowa City, 3; Stephenson, "Typical American Letters," 77, 90, 95; Ferdinand Larson and Betty Larson, interview with author, Swedesburg, 1981. According to George S. Cole, Cole's Encyclopedia of Dry Goods (New York, 1900), 199, flannel was a "coarse-threaded loosely woven woolen material" usually fulled to give it stability and had a napped surface. Producers variously teasled, sheared, and pressed it for different surface effects. Warp threads are the longitudinal or vertical yarns under tension on a loom. The crosswise filling yarns-variously known as weft, woof, or picks-are woven through the warp yarns and form the selvage edges of the fabric. 
manufacture," "staple goods," and "household manufacture." The society published the first report after the 1854 Fairfield fair in Jefferson County. From 1854 through 1880, many southeast Iowa weavers entered their woven textiles. They entered plain woolen cloth and a variety of flannels from 1854 through 1875 , woolen carpet from 1858 through 1875 , and pairs of woolen blankets from 1854 through $1880 .{ }^{13}$

Linsey-woolsey or linsey was a hand-woven fabric frequently mentioned in secondary accounts of the lowa frontier: "A kind of cloth called linsey-woolsey was made out of both wool and flax thread; it was common cloth for girls and women's dresses." Weavers commonly wove linsey-woolsey with a warp of linen and a weft of wool; people considered it a coarse variety of flannel. The authors found no pieces of linseywoolsey in southeast Iowa collections nor was it among the "staple goods" of household manufacture listed in any of the Iowa State Agricultural Society proceedings.

A number of Iowa histories also mention jean, another handwoven fabric. These histories generally view the pioneers' use of coarse homespun as evidence of their hardship: "Most of the clothing was home-made of buckskin and coarse jean for the men and linsey and calico for the women. Little or no attention was given to fashion in those days: utility and lack of skill determined the lines of the finished product. "Store clothes' were practically unknown." Jean was a variety of stout twill cloth, properly woven with cotton warp and wool weft, but often composed entirely of cotton. It was usually twentyseven to thirty inches wide and the woolen weft, if used, was commonly blue, brown, or slate. Its name varied among "jean," "jeans," "janes," and "jaynes." Kitturah Belknap wrote in November of 1842 that she had made "enough for two pairs of pants." 14

13. The Iowa State Agricultural Society reports began with Report and Proceedings of the Iowa State Agricultural Society held at Fairfield, Iowa in October, 1854 (Keokuk, 1855) and ended with Forty-Sixth Annual Report of the Board of Directors of the lowa State Agricultural Society for the Year 1899 (Des Moines, 1899). The report titles varied from year to year. For all volumes see Annual Report of the Board of Directors of the Iowa State Agricultural Society, Iowa State University Library, Ames.

14. Quotation on linsey-woolsey is from Aurner, Iowa Stories, 88. See also Cyrenus Cole, History, 247; Faragher, Women and Men, 54; Gallaher, "Iowa Pioneers"; Duffield, Memories, 25; Murray, "Memoir of the William Archer 
No known specimens of jean are available in southeast Iowa, but the fabric appeared as an entry in some state and county agricultural fairs. In 1854, the Bloomfield Democratic Clarion announced awards planned for household manufacture in the upcoming Davis County Agricultural Fair. Exhibitors, could win prizes for the best pair of woolen blankets, ten yards of woolen cloth, ten of "janes," ten of woolen carpet, and the best coverlet. An 1858 issue of Ward's Own, also from Bloomfield, listed monetary awards planned for the September fair of the Davis County Agricultural Society. This fair offered household manufacture awards for white and plain linsey, white and plaid flannel, mixed jeans, wool blankets, coverlets, counterpanes, pieced quilts, rag carpeting, socks, stockings, and "stands" of curtains. Southeast Iowa weavers won premiums for jean fabric in the state agricultural fairs of $1855,1856,1859$, and $1878 .{ }^{15}$

FLAX was another raw material used to weave cloth in the nineteenth century. Many historians have repeated their belief that each pioneer woman in lowa raised her own patch of flax to provide the raw materials for carding, spinning, dyeing, weaving, and knitting. Judging from the extant evidence of raw materials which handweavers used, however, they produced linen textiles in much smaller quantities than they did woolens. Census takers recorded the production of flax fiber in the state by 1850 . From 1850 through 1870 , censuses show that flax growing occurred in southeast Iowa. But only two counties, Davis and Keokuk, were growing enough flax to provide one or more pounds of fiber per person from 1850 to 1863 . All other counties in the southeast region were growing very little flax. From 1863 through 1870, only Henry, Johnson, and Muscatine counties had sizeable quantities of flax. Even this flax may not have all gone into home manufacture. Flax was also a suitable

Family." See Robeson, "Hard Times," 167, for quote on pioneer clothing. For definitions see Cole, Cole's Encyclopedia; Ellen J. Gehret, Rural Pennsylvania Clothing (York, 1978), 283.

15. For Belknap see Riley, "Family Life," 41. Bloomfield Democratic Clarion, 15 September 1854; Wards Own, 10 June 1858; Report, Iowa State Agricultural Society (hereafter ISAS), (Fairfield, 1856); Report, ISAS (Muscatine, 1857); Report, ISAS (Des Moines, 1860); Report, ISAS (Des Moines, 1879). 
cash crop for shipment to out-of-state markets and for sale to local industries which used it to manufacture linen cloth, cord, rope, and linseed oil. Also, Johnson County had a commercial flax manufacturer from 1868 to 1888 . Regardless of the amount of flax that became a cash crop, evidence indicates that some flax supplied home textile production in southeast Iowa as early as 1839 and through $1875 .^{16}$

In 1909, W. S. Wilkinson described raising flax for "summer wear" in 1840s Iowa. Wilkinson's account concerns Madison County, but the process would be somewhat similar in southeast Iowa. Gibson Anderson also wrote about his grandparents' family in Davis County raising flax in the 1800s. Together these accounts present a detailed picture of flax raising. Farmers planted the flax seed in early spring and when the plant was ripe, pulled it up by the roots. Wilkinson recorded that the harvesters then bound the flax in bundles and "shocked" it to dry. The seed was "whipped off and the flax was then put in water to rot the stem so it would separate from the lint, then spread out to dry." Anderson wrote that his grandmother's family took the flax to a meadow after pulling it up and laid it out to dry. They left it until the stems rotted and then raked it up. The next step was "breaking," or using the flax brake to remove the "sticks" or "straw" from the fibers within the stems. Anderson's ancestors used a "scutching knife" to whip the flax. Wilkinson instead recalled holding the flax on top of a "swingling board" with one hand and knocking out "the

16. For historical beliefs concerning flax growing see Gibson Anderson's, Helen McLeran's, and Prudence Gregg Tomlinson's essays, "The Story of My Grandmother," MS, 1923, ISHD, Iowa City; Aurner, Iowa Stories, 80, 87-88; Dubell, "Rural Pioneering"; Faragher, Women and Men, 54-56, 65; Hamilton, "History of the Hamiltons"; Petersen, Story of Iowa, 364; Welty, A Fair Field, 48-49; W. S. Wilkinson, "Early Days on the Middle River," MS, 1904, ISHD, Iowa City. For evidence of flax production see Census Board, The Census Returns of the Different Counties of the State of Iowa for 1856, for 1859 , and for 1867 (Des Moines, 1856, 1859, 1867); U.S. Bureau of the Census, The Seventh Census ... 1850; Population of the United States in 1860, Volume 1 (Washington, D.C., 1864); The Statistics of the Population of the United States (Ninth Census, 1870), Volume 3 (Washington, D.C., 1872). See also the 1868 , $1878,1884,1886$, and 1888 reports of C. A. Dockham, all published in Boston, and variously titled The Dry Goods Trade, and Cotton, Woolen, Silk, and Linen Manufacture of the United States or Dockham's American Report and Directory. 
shives" with a "swingling knife" in the other. Thus names for the same tools and processes varied as did methods from region to region. Next one drew the bundle or stalk of flax fibers through a hackle to separate the tow, or short fibers, from the line, or longer fibers. Wilkinson said that weavers used the best of tow to make coarse garments for little boys: "There was tow pants and shirts. The long tow shirt was quite a novelty being worn without pants-cool in warm weather." Anderson mentioned that weavers usually spun tow for everyday clothing while they saved the finer fibers for bed linen, table linen, towels, and better clothes. The coarser parts of the tow cloth, "made from the short-fiber, darker parts of the flax, was used for toweling, bandage, menstrual cloth, rags, or rough field clothing" as well as for pillows and mattresses. ${ }^{17}$

Extant tools specifically related to the production of linen thread are more solid evidence of early weaving than are wool cards or spinning wheels. While linen hose or stockings, most likely knitted, appeared occasionally as entries for the Iowa State Agricultural Society fairs (in 1865, 1873, and 1877), flax was less desirable than wool for knitted textiles because it lacked elasticity. It was much more suitable for woven items. Of all the tools needed to process flax, the authors found only hackles in the collections examined, variously identified as "heckles," "hatchels," and "hetchels." They survive singly and in pairs in lowa museums. Museum workers have labeled them as used with flax or wool, but the coarseness of the pointed metal teeth set on a stationary board suggests that these hackles were for flax rather than wool. Museums often have two of these hackles together, as they do wool cards, but weavers used hackles consecutively. A weaver would first use the board with teeth set further apart from each other, and then use the finer toothed board to remove more tow and prepare the flax for the spinning distaff. ${ }^{18}$

Home weavers who did use flax used it for warp and weft yarns as well as for sewing thread. Kitturah Belknap recorded in 1839: "All winter I have been spinning flax and tow to make

17. Wilkinson, "Early Days," 5; Anderson, "Story of My Grandmother," 5; Faragher, Women and Men, 54-55.

18. Report, ISAS, 1854-1899 passim. 
summer clothes." In the following spring, she wove a homemade everyday dress of "cotton warp colored blue and copper and filled with pale blue tow filling so it was striped one way and was almost so nice as gingham." She did not give a name to this cloth of linen and cotton. When preparing for a move to Orgeon in 1847-48, Belknap planned to make a linen wagon cover.

Will make a muslin cover for the wagon as we will have a double cover to keep warm and dry; put the muslin on first and then the heavy linen one for strength. They both have to be sewed real good and strong. I have to spin the thread and sew all those long seams with my fingers then I have to make a new feather tick for my bed. I will put the feathers of two beds into one tick and sleep on it.

By February she had spun the thread for a linen wagon cover and for six two-bushel bags to hold flour and other staples on the trip. ${ }^{19}$

Some other accounts of making clothing from woven flax survive. Prudence Elizabeth Billingsly's family of Jefferson County spun flax to weave sheets during the 1850 s and 1860 s. The Thomas Brown family also raised flax which they processed. and spun themselves to weave linen pants and linsey dresses. They came to Wapello County, Iowa from Ohio in 1846. Thomas J. Hamilton described his ancestor Thomas Brown's linen trousers as "made in a peculiar style. Something like the Navy boys' pants today, but not 'so tight fitting.' Instead of buttoning up the center of the front, they had a flap with a row of buttons on each side. I only knew one other Irishman, John McCarty, who had them that way." Margaret Archer Murray, in reminiscences about her mother's family, reported Iowans wearing linen trousers as well. At least one example of linen clothing also survives in an Iowa museum. A pair of linen broadfall trousers or pantaloons found in the Lewelling Quaker Shine at Salem, Iowa are probably similar in style to Thomas Brown's. Owen Garretson wore these pants, which his mother, Elizabeth Garretson, wove and handmade. This family came

19. Riley, "Family Life," 35, 47-48. 
to Salem in 1837 and the mother died in 1887 , therefore the pants must date from within this fifty year period. ${ }^{20}$

Although firsthand descriptions of flax weaving and extant samples of flax textiles seem limited, a variety of linen fabrics and products from southeast Iowa weavers won premiums at the Iowa State Agricultural Society fairs from 1854 through 1875. "Barred" (striped) linen, table linens, and tow linen or cloth were entries in the 1850 s. Linen cloth, in ten-yard quantities, plus linen sheets, linen hose or linen thread stockings, and spun flax or linen thread were entries in the 1860s and 1870s as well. Nevertheless, flax was less common in southeast Iowa home textile production than wool. The awards given handwoven wool textiles consistently outnumbered those given woven linen products at all of the fairs. From 1854 through 1899, premiums for wool staple goods were over three times as prevalent among the listings as were premiums for linen goods. ${ }^{21}$

Growing flax for homeweaving may have been uncommon in southeast Iowa for reasons to do with the raw material itself. Ferdinand Larson of rural Swedesburg in Henry County recalled that flax was a good first crop on the frontier because it helped to break down the rootbound prairie. Yet a sterile crop, such as potatoes, was necessary the following year, because flax used up precious nutrients in the soil. Flax may have been suited only to new land also because a soil fungus developed quickly where flax grew. Flax production required extensive precautions and expertise. Knowledge of the best soil type, sowing techniques, how best to dry the plant after pulling it from the roots by hand, how to ret it by dew or water to prevent excessive darkening, how to keep the fibers flexible enough for spinning, and how to scutch properly to avoid weakening or breaking the fibers were all critical to flax production. Some flax growers stored the plant in a dry place for a year after pulling because they believed a maturing process improved the quality of the fiber. Spinning linen thread also required a distaff on a spinning wheel and greater skill than

20. Tomlinson, "Story of My Grandmother," 3; Hamilton, "History of the Hamiltons," 4-5; Murray, "Memoir of the William Archer Family," 361.

21. Report, ISAS, 1854-1899 passim. 
did wool spinning, as flax has no natural oils to facilitate twisting the fibers into a strong yarn. The risks of repeatedly growing flax in the same location, as well as the extensive expertise, time, and equipment required to process the fiber into yarn, could account for flax's relative unpopularity among weavers in southeast Iowa. ${ }^{22}$

Although historians have included hand-woven cotton among the fabrics which early Iowa settlers produced, there is very little evidence that any Iowa home weavers produced or spun cotton. There was one entry of cotton yarn in the Iowa State Agricultural Society fair of 1863 . Southeast Iowa newspapers did advertise cotton thread for sale. On October 12, 1841, merchants Bridgeman and Partridge of Burlington advertised in the Hawkeye and Iowa Patriot that they had three tons of cotton yarns. Merchant J. S. McVey advertised a few hundred pounds of cotton for sale in the February 1, 1844 issue of the Davenport Gazette. A store's account book from the town of Rose Hill in Mahaska County, which covered August 1855 to November 1857 , mentioned sales of bunches of cotton, one bunch costing $\$ 1.30 .23$

Most written sources and surviving artifacts suggest that almost all cotton used in southeast Iowa was store-bought. Coverlets tend to be the only extant hand-woven textile containing cotton thread, and they reinforce this conclusion. While most coverlets have cotton warp threads, the warp appears to be machine spun rather than hand spun. Many coverlets that survive in southeast lowa carry incorrect labels from relatives or descendants of the original owners which describe them as woven from the flax and wool which the owner raised. Machine-spun cotton appears to have been both the warp and weft of all coverlets examined. Thus cotton was available as commerical yarn for hand weaving or knitting in southeast

22. Larson, interview, 1981; Melloh, "Life in Early New Sweden"; Elsie G. Davenport, Your Handspinning (Pacific Grove, Ca., 1971), 79-90.

23. Cotton bunches may mean carded cotton or skeins of cotton yarn. Faragher, Women and Men, 54, mentions the use of bunches of carded wool for spinning. In this context bunches is synonymous with rolls of carded fibers. See also Ninth Report, ISAS (Des Moines, 1864); Hawkeye and Iowa Patriot, 12 October 1841; Davenport Gazette, 1 February 1844; Anna L. McDonald, store account books, Rose Hill, 1855-1857 passim, ISHD, Iowa City. 
Iowa but Iowans did not commonly spin or grow cotton at home.

Cotton and wool overshot coverlets and wool blankets are the most abundant existing examples of nineteenth-century hand-woven textiles in Iowa. The excellent condition of many surviving coverlets indicates that some received little use and their weavers may have intended them to be heirlooms, while other textiles were meant for regular use. In the thirty-five public and private collections included in this study, are seven wool blankets and six overshot coverlets (some in pieces or fragments) believed to be products of Iowa hand weavers. Most of these blankets or pieces of blankets are loosely woven weft-faced fabric and the surface is commonly felted. Typically, hand-woven coverlets are overshot weave, with natural or white cotton warp and weft tabby and navy blue wool weft. All of the overshot coverlets found have a center lengthwise seam, and one-half the width is usually thirty to thirty-five inches, so home weavers probably produced their coverlets on looms that were not much wider than forty inches. The woven patterns suggest that these looms had at least four harnesses. Overshot coverlets were one of the few products of home weavers that power looms or commercial mills did not also produce. Their patterns, and thus their weave structure, were more complex than the capabilities of most power looms used in ninteenth-century Iowa mills. Southeast Iowans appear to have woven single and double coverlets, as well as pairs of wool blankets, throughout the 1850s, 1860s, and 1870s, judging from the entries at the Iowa State Agricultural Society fair as well as from other evidence. ${ }^{24}$

Looms and tools preserved in Iowa's museums and private

24. Weft-faced fabrics are those with closely spaced weft yarn. The warp yarns do not show. This may be a result of the woven structure or of felting and shrinkage after the cloth is off the loom. Felting, usually done with wool fibers, involves matting and entangling the fibers by applying heat, water, and/or pressure. An overshot weave produces a pattern of floats on a plain weave (tabby) ground. In overshot coverlets, the floats-weft yarns that travel over at least two warp yarns without interlacing-are usually dyed wool yarns while the tabby consists of white or natural colored warp and weft yarns woven in a plain weave. Harnesses are frames, hung on a loom, that hold vertical wires or strings. Each wire or string, called a heddle, has a loop in the center through which each warp end passes. 
collections serve as further evidence that Iowans practiced hand weaving. Pamela Maxwell, who lived near Salem in Henry County in 1838, owned the first loom west of the Mississippi, according to an undated newspaper clipping. The loom was a barn frame type, which a local carpenter made of native lumber and which included six foot, six-by-six corner posts. This was representative of most looms built and used in lowa. The majority of extant looms have two to four harnesses hung from an overhead horizontal beam by leather pieces or wooden pulleys, and overhead beaters. Hanging the beater and harnesses from overhead beams required the construction of a large cube-shaped frame for the loom, which inspired the common tern "barn frame loom." Most surviving looms were wooden and pegged together with minimal use of nails or metal. Because of the prevalence of barn frame looms in lowa museum collections, it seems likely that they were the most common type which home weavers in southeast Iowa used. Many looms, however, were preserved in pieces, so that their type or number of harnesses is unknown. ${ }^{25}$

The simple design of most barn frame looms made it possible for anyone familiar with tools to construct one from local woods. Settlers built many looms locally as needed, "and in one county during the winter of 1839 at least nine looms were built." With an ax, a drawing knife, an auger, and a saw, a settler could make a loom as well as the spinning wheels and reels on which to wind the yarn. Daniel Nelson of Jefferson County made a loom from hand-hewn logs and wooden pegs sometime between 1857 and 1866. It is now preserved in the Fairfield Public Library. A cabinetmaker who emigrated from Sweden, Nelson constructed the loom so his wife could weave blankets and cloth for underwear just as she had done in Sweden. The weight and size of a loom made its transportation prohibitive in the nineteenth century, so no known looms from out of state exist in the collections visited. A barn frame

25. Edith MacNulty, "Highways and Byways," clipping, no date, Henry County Historical Society, Mt. Pleasant. The beater or batten is the part of a loom which holds the reed, which keeps the warp ends evenly spaced. Both serve to beat the weft or filling yarns in place as the weaving progresses. Overhead beaters swing freely from the top of the loom rather than being fastened to the loom near the floor. 


\section{Home Weaving}

loom in the Jonathan Conger House in Washingtron, Iowa supposedly came to Muscatine from New York State in the $1850 \mathrm{~s}$, but no evidence exists to verfiy the original owner or to relate how the loom got to Iowa. ${ }^{26}$

Southeast Iowa weavers may have acquired their looms through the efforts of family members or neighborhood carpenters. Also, in the 1850 s and 1860 s, craftspeople were patenting hand looms in Iowa. Of the forty-seven U.S. patents issued for hand looms from 1790 to 1873 , fourteen were issued to individuals or partnerships in Iowa. Seven of these patents went to ten different individuals in Salem, Iowa from May 1850 to August 1866 and all but one of the fourteen patents went to men in the southeastern quarter of the state. These men would hardly have patented their loom designs unless they intended to produce them for sale. The patent descriptions identify all of the Iowa hand looms as two-harness or four-harness looms, except for one that W. B. Walker and N. D. Hartley of Salem, Iowa patented in August 1866, which was a six-harness loom. In contrast to other states, Iowans patented hand looms to the apparent exclusion of power looms. In this same period, the government issued thirty-four patents for power looms, all to inventors in Pennsylvania and states further east. 27

An 1867 report of the Iowa State Agricultural Society showed line drawings and short descriptions of two hand looms then available in Iowa. One was "Whitehead's Excelsior Loom" made by John Whitehead and Wesley Goss at Oskaloosa, Iowa. It looked like a four-harness barn frame loom. J. Whitehead received a patent for a hand loom on December 4, 1866. This loom's price, "with two shuttles, two reeds, steel wire, harness, and fifty bobbins" was one-hundred dollars. The description in the Iowa State Agricultural Society report claimed that "six

26. Aurner, Iowa Stories, 97. The Fairfield Public Library in Jefferson County has Johanna Nelson's loom and a photograph of the Nelson couple on exhibit along with a brief biography and description of weaving. Also see Ardith K. Melloh, "New Sweden, Iowa," Palimpsest 59 (January/February 1978), 2-39.

27. U.S. Patent Office, Subject-Matter Index of Patents for Inventions Issued by the United States Patent Office from 1790 to 1873, Inclusive, 3 vols. (Washington, D.C., 1874), 2:881-884. 
different styles of goods have been made, without leaving the loom, and is done by a different step on the treadle. In 12 hours, 85 square yards (seamless blanket) have been woven." An iron hand loom by Wait, Gallup \& Co. of Watertown, Wisconsin also appeared in the 1867 report at the price of one-hundred dollars, and could "weave all kinds of cotton and woolen goods." The company had sold thirty such looms in lowa in $1867 . .^{28}$

The 1869 report of the Iowa State Agricultural Society listed $\mathrm{J}$. and $\mathrm{H}$. Henderson of Keokuk, Iowa as receiving a diploma and ten dollars for the best hand loom entered. The classification under which one could enter hand looms was "Churns, Washers, Wringers, \&c." J. Henderson had patented a hand loom made in Palmyra, Missouri in 1861 and J. G. and H. T. Henderson patented a hand loom made in Salem, Iowa in 1865. The 1870 census also listed John Henderson as a manufacturer of looms in Keokuk. In 1874, H. T. Henderson received another diploma and ten dollars for the best hand loom entered at the Iowa State Agricultural Society fair. The Iowa Mennonite Society Museum in Kalona has a Henderson loom with a patent inscription dating it 1865. Although the design does not correspond to the patent issued to J. G. and H. T. Handerson in March of 1865 , the same Hendersons probably made it. ${ }^{29}$

HAND WEAVERS who produced goods for their own and their families' consumption generally eluded documentation and so it is impossible to calculate the number of them in southeast Iowa. The federal census returns, however, from 1850 on, did identify those people who considered weaving to be their occupation. In 1850, the census listed nineteen people as weavers within the sixteen-county area of southeast Iowa. In 1856, this number had more than tripled; sixty-eight weavers were working in the same area. Because the population in southeast Iowa had grown so by 1860 and 1870 , a reduction (by half) in the number of county returns searched for weavers became

28. Ibid., 882; Report, ISAS (Des Moines, 1868), 246, 255.

29. Report, ISAS (Des Moines, 1868); Report, ISAS (Des Moines, 1870); Report, ISAS (Des Moines, 1874); U.S. Patent Office, Subject-Matter Index, 881. U.S. Bureau of the Census, unpublished original census returns for lowa counties in 1870 . 
necessary. In eight southeast lowa counties, there were forty weavers in 1860 and thirty in 1870. All of these figures include male and female weavers, but only those who viewed weaving as their gainful employment, who produced a surplus for sale, would have received the professional designation. Many home weavers who did not claim weaving as a profession must remain anonymous. ${ }^{30}$

Letters and diaries that document the existence of some of these unnamed and uncounted home weavers shed light on both the reasons they continued to weave in Iowa and the value of their contributions to southeastern Iowa families through 1870 . Historians have suggested that early settlers had no access to commercial goods and so had to produce their own textiles or do without. Necessity may have motivated some, but not all, Iowa weavers. Weavers in southeast Iowa may have also continued their craft past the point of necessity to supplement their family incomes by selling textiles to neighbors and friends, to decrease dependency on expensive commercial goods, to gain personal satisfaction from continuing a learned skill, or to prepare for travel westward to new frontiers where manufactured goods were still not available.

Only settlers in counties inland from the Mississippi, with no navigable rivers and no railroad transportation until the 1860 s and 1870s, may have had to produce their own textiles and clothing or do without. The southeast Iowa counties without navigable rivers-Davis, Iowa, Jefferson, Keokuk, and Washington-probably had less access to commercial goods than did other counties prior to regular railroad service. Except for Washington, railroad service to each of these counties developed gradually through the 1860 s and 1870 s. While census takers did not record the number of home weavers in each county, they did record that Davis, Iowa, Jefferson, Keokuk, and Wapello counties maintained the highest degree of "domestic manufacture" from 1850 through 1870. Census authorities defined domestic manufacture as "all household manufacture not included in dairy products; that is to say

30. U.S. Bureau of the Census, unpublished original census returns for Iowa counties in 1850,1860, 1870. Census Board, The Census Returns for the Different Counties of the State of Iowa for 1856. 
fulled cloths, flannel, linen and tow cloth, cotton and mixed goods, maple sugar, etc., etc." ${ }^{\prime 31}$

The earliest Iowa newspapers from Mississippi River towns and old store account books show that a large variety of textiles was available at local stores in southeast Iowa, as early as 1836. By the time Iowa became a state in 1846 there were ninety-one dry goods dealers in the southeast region. The river towns of Burlington, Fort Madison, and Bloomington (Muscatine) supported over half of these stores. John Newhall's travel guide, A Glimpse of Iowa in 1846, written to encourage immigration to the new state, reported that, "in all the principal towns of lowa, most every article, both necessity and luxury, will be found at the stores, in almost as great variety as the large establishments of the eastern cities." Even allowing for exaggeration on Newhall's part, newspaper advertisements and store account books reveal that broadcloth, cassimere, satinet, linsey, Kentucky and Keokuk jeans, drilling, and linen were all available for purchase as were finer French and English velvets, silks, calicos, cambrics, and chintzes..$^{32}$

31. C. C. Cooper, The Role of Railroads in the Settlement of Iowa: A Study in Historical Geography (M. A. thesis, University of Nebraska, Lincoln, Neb., 1958). U.S. Bureau of the Census, The Seventh Census ... 1850; Population of the United States in 1860, Volume 1, The Statistics of the Population of the United States (Ninth Census, 1870), Volume 3; and Census Board, The Census Returns of the Different Counties of the State of Iowa for 1856 and for 1859; Hull, 1836-1880. Census of Iowa for 1880, p. XX.

32. Quotation from Newhall, A Glimpse of Iowa in 1846, 60-61. Also surveyed were Bloomington Herald, 1846-1848 passim; Burlington Patriot, 1838; Davenport Gazette, 1843-1844 passim; Hawkeye and Iowa Patriot, 1840-1841 passim; Iowa Territorial Gazette, 1839-1840 passim; Lee County Democrat, 1843-1852 passim. The store account books surveyed in the ISHD, Iowa City collection were from G. R. Espy, Fort Madison, 1848-1849 passim; S. Kirkwood, Iowa City, 1845-1858 passim; and A. L. McDonald, Rose Hill, 18551857 passim. See also Glenda Riley, Frontierswomen: The Iowa Experience (Ames, 1981), 69-76, and Newhall, A Glimpse of Iowa in 1846, 60-92. Cole, Cole's Encyclopedia, defines broadcloth as a high grade, lustrous woolen cloth, considerably fulled and slightly napped; cassimere as an original American product that ranged in quality from an inexpensive fabric of cotton warp and reprocessed wool weft to a fine all-wool fabric; satinet as a fabric made with cotton warp and wool weft specifically for use in men's trousers; and Kentucky jeans as a general name applied to various grades of jean fabric, whether made in Kentucky or elsewhere, because the Kentucky woolen mills had built a reputation for the quality of their jeans. We presume Keokuk jeans refers to cloth woven by a mill in Keokuk. Drilling was a generic title for several varieties of cheaper, stout-twilled cotton and linen cloth, used for linings, pockets, bedding, and similar purposes. Cambric properly refers to a fine, plain woven linen but also was a name for thin cotton muslin. 
Granted, commercial textiles may not have been available in sufficient quantities to meet all of the demand at that time. Also, settlers in towns further west may not have had access to commercial cloth as early as those who lived on the Mississippi. Commercial shipping began, however, on most southeast Iowa rivers soon after 1833, when settlement received formal sanction. A steamboat loaded with cargo traveled from Keokuk to Keosauqua on the Des Moines River in 1837. A steamboat traveling on the Cedar and Iowa rivers reached Iowa City with merchant goods in 1841 . Settlers in Wapello and Mahaska counties to the west soon saw steamboats on the Des Moines River. The railroad, which reached many southeast counties by the 1850 s, probably brought an even wider variety of goods to the area. As historian Glenda Riley determined, after surveying Iowa's frontier newspapers of the 1830s through 1850s, "the wide availability and use of these goods does not uphold the stereotype of frontierspeople always dressed in rough homespun and animal-skin clothing. Conditions of grinding poverty on the prairie frontier-at least in pioneer lowa-were brief and transitory for many frontierspeople."

Most home weavers did not sell cloth on a regular basis, but occasionally sold it or exchanged it for goods among neighbors to supplement family income. In the spring of 1840, Kitturah Belknap wrote that she had been spinning flax in all of her spare time through the winter and that she had made a piece of linen to sell. In June of 1865, Mary Stephenson wrote from New Sweden that she intended to sell some cloth. The previous fall she had sold some hand-woven cloth to her nearest neighbor for two dollars per yard. In November of 1867 , Stephenson wrote to her Swedish parents from her new home in Freeport (now Swedesburg): "Weaving for others is a very profitable employment in this country, wages being twenty cents per yard for coarse weaving. Generally speaking, the Americans do not know how to weave, nor do Swedes who are brought up here. But they do know how to sew-it is necessary to sew almost everything." Many lowa farm women

33. Tacitus Hussey, Beginnings: Reminiscences of Early Des Moines (Des Moines, 1919); William J. Petersen, Iowa: The Rivers of Her Valleys (Iowa City, 1941); Glenda Riley, Frontierswomen, 70. 
made resourceful contributions to their family economies through weaving. Historian Dorothy Schwieder has found that the farm wife "who did not bring some cash into the home or at least reduce cash outgo by bartering for necessary goods and services, appears to have been the exception rather than the rule." Weaving was a source of cash income for women before many worked outside the home and perhaps supported some women when death or separation removed the male wageearners from their midst. ${ }^{34}$

A scarcity of cash to spend on commercial goods appears to have been another reason why Iowans pursued home weaving. In the 1840s Swedish settlers found Jefferson County textiles too expensive in relation to what they could get for their home products such as eggs and butter. In that county in 1846, a farmer could sell a pound of butter from home manufacture for five cents and a dozen eggs for three cents, but a yard of calico cost twenty-five cents and yard of muslin, sixty cents. Johanna Nelson immigrated to New Sweden in 1857 and was one of the immigrants who continued to weave as she had done in Sweden. Her motivation to weave may have been economic need for cloth to use herself or to barter. She also may have associated home weaving with a pride in her national heritage and seen the importance of hand skills passed from one generation to another. ${ }^{35}$

Personal financial necessity and statewide economic "panics" and depressions may have prompted other families to produce their own cloth. Certainly settlers were hard pressed for food and shelter when they first arrived in Iowa. They may have had little with which to barter for store clothing. Kitturah Belknap and her husband, when they arrived in Van Buren County in 1830, were prepared for conditions that were probably typical for families on the 1830s Iowa frontier: "Now we must save every dollar to pay for our land. We had clothes to last the first year, and we got a dollar's worth of coffee and the same of sugar that lasted all winter and till corn was planted."

34. Riley, "Family Life"; Stephenson, "Typical American Letters," 90; Dorothy Schwieder, "Labor and Economic Roles of Iowa Farm Wives, 184080 ," in Farmers, Bureaucrats and Middlemen, ed. T. H. Peterson (Washington, D.C., 1980), 153.

35. Melloh, "New Sweden, Iowa." 
Near the end of their first full year in Iowa, Belknap could record proudly: "Did not have to buy any clothes this year so we have skimped along and have $\$ 20.00$ to put in the box (all silver)." She had accommodated their clothing needs by spinning and weaving wool and flax over the year. ${ }^{36}$

The year 1843 and the winter and spring of 1856-57 were times of particular hardship for Iowans. They experienced economic depression in 1843, when "agricultural produce was difficult to market and brought little money, while commodities needed by the settlers were relatively dear." The winter of 1856-57, as well as the next one, were unusually severe. Susan Wyatt and her children, near Grinnell, wove and sewed all their household textiles and clothing after the 1857-58 winter. The season and the economic depression were especially difficult for the Wyatts, whose husband and father had deserted them. Hand weaving and sewing enabled some families such as the Wyatts and Belknaps to replace worn clothing and household textiles when they did not have the money to buy commercial goods. ${ }^{37}$

The amount of hand weaving undertaken because of economic need may have increased during an economic panic in the late 1850s and the start of the Civil War in 1861. An 1862 report from the commissioner of agriculture predicted that the Civil War might check the previous decrease in home manufactures, "for the high prices of cotton and wool have so advanced the prices of manufacture generally that home-made goods resume their former economical value." War shortages caused prices to rise. Mary Stephenson's husband, Oliver, wrote to friends in Sweden in November 1863 that "the price of textiles has risen four fold since the outbreak of the war. Clothing is expensive." In August of 1864 he enumerated wartime prices.

Prices are unusually high. A horse brings from $\$ 100$ to $\$ 150$; a cow, $\$ 25$; a yoke of oxen, $\$ 100$; a hog $\$ 10$; wheat, $\$ 2$ per bushel; rye, 90 cents; corn, 75 cents; potatoes, $\$ 1.25$; pork, 15 cents per pound; beef, 10 cents; butter, 20 cents; cheese, 15 cents; eggs, 12

36. Riley, "Family Life," 34-35.

37. Robeson, "Hard Times," 165; Vesta Robbins, No Coward Soul (Ames, 1974). 
cents per dozen. Everything we buy is four times as expensive as formerly. Cotton cloth a yard and a half wide which formerly cost 10 cents now brings 75 cents, and everything else in proportion.

Stephenson also mentioned that his uncles were working for others at "six dollars per day, but living consumes half." Civil War prices may have encouraged the resurgence of home weaving by raising prices; it was not until December of 1866 that Stephenson wrote: “Textiles have gone down so that they are just half as expensive as formerly. The falling prices are carried by the declining price of gold. I think prices will soon be normal." ${ }^{\prime 38}$

The desire to continue a learned skill, often connected to ethnic or family traditions, may have motivated many hand weavers as well. The hand weaving of rag carpets, which continued well into the twentieth century, may have been a means to perpetuate a learned skill and to use equipment no longer needed to produce cloth or clothing. Producing woven rugs was economically feasible after the need for hand-woven cloth had passed, since the rugs' weft was often cloth strips cut from worn fabric which no longer served its original purpose. Rug weavers also used commerical cotton warp and thus eliminated the need to spin yarn at home. Henry $C$. Taylor recalled that the last use of his mother's loom was for carpets. Mary Stephenson was preparing to weave carpets in May of 1867. She wrote to her parents: "I have made preparations to weave carpets for our floors. I have sheared thirteen sheep, and have forty pounds of wool." In a November letter of the same year, she had "twenty-four yards of carpet and have furnished two rooms." The proceedings of the Iowa State Agricultural Society indicate that rag carpeting was part of household manufacture from 1854 through 1899, the last year that the society published a report. "Rug weaver" was one of the business establishments listed for Swedesburg in the late 1860s. ${ }^{39}$

38. Report of the Commissioner of Agriculture for the Year 1862 (Washington, D.C., 1863), 554. Stephenson, "Typical American Letters," 69, 73-74, 83.

39. Taylor, Tarplewick, 28-29; Stephenson, "Typical American Letters," 87, 90. Report, ISAS, 1854-1899, passim. Carl A. Anderson, "The Saga of Swedesburg," Annals of Iowa 35 (Winter 1960), 187-205. 
Hand weaving may have continued as a particularly valued skill among those families preparing to travel westward. Many settlers used Iowa as a stopping point until they could raise the money to go farther west. Kitturah Belknap was very busy during the winter of 1847-48 with spinning, weaving, and sewing to get ready for a move to Oregon.

November, 1847. Have cut out four muslin shirts for George and two suits for the little boy (Jessie). With what he had that will last him (if he lives) until he will want a different pattern.

Material for men's outer garments has to be woven yet...

Now I will begin to work and plan to make everything with an eye to starting out on a six month's trip. The first thing is to lay plans and then work up to the program. The first thing is to make a piece of linen for a wagon cover and some sacks. Will spin mostly evenings while my husband reads to me. The little wheel in the corner doesn't make any noise. I spin for Mother Belknap and Mrs. Hawley and they will weave. Now that it is in the loom I must work almost day and night to get the filling ready to keep the loom busy. The men are busy making ox yokes and bows for the wagon covers and trading for oxen.

February, [1848]. The linen is ready to go to work on and six two bushel bags all ready to sew up. That I will do evenings by the light of the dip candle for I have made enough to last all winter after we get to Oregon. Now my work is all planned so I can go right along. Have cut out two pairs of pants for George (homemade jeans).

In March, Kitturah Belknap wrote that she had "worked almost day and night" during the winter even though she had not woven all the fabric that had gone into their new clothing. "I have sewing about all done but a coat and vest for George. He got some nice material for a suit and had a tailor cut it out." When the Belknaps began packing their wagon in April of 1848 , they loaded "long sacks of flour and other things. The sacks were made of homemade linen and will hold 125 pounds. There are four sacks of flour and one of corn meal." Belknap also packed a few "luxuries": "I am going to start with good earthen dishes and if they get broken I have tin ones to take their place. Have made four nice little table cloths so am going 
to live just like I was at home." Probably only those women who had been weaving regularly would weave a surplus of cloth for such trips westward. Perhaps others would purchase manufactured cloth and clothing before leaving Iowa since supply stations along the trails west were very limited. Comfortable settlement at new locations in the West no doubt required sufficient clothing to last a year or more until the family had raised and sold its crops, just as had been the case for early Iowa settlers. ${ }^{40}$

Evidence of raw materials, looms, and a variety of fabrics shows that hand weaving was part of home manufacture in southeast Iowa through 1870 . Kitturah Belknap, Mary Stephenson, and the few other weavers who left firsthand accounts of their textile production were exceptional only in that they recorded their day-to-day activities. Perhaps they recorded their endless labor because they sensed a value and importance in what they did for their families as well as for future generations. Evidence indicates that hand weaving was gradually declining through the second half of the nineteenth century as it gave way to factory production of cloth. For example, the awards given to hand-woven goods at the Iowa State Agricultural Society fairs decreased in proportion to those given other household products and "fancy goods." From 1854 through 1861 , awards given woven goods varied from 22 to 35 percent of all awards given household manufactured products, with the exception of 1860 , when only 13 percent of the home textile goods awarded premiums were hand woven. In the war years of 1862 and 1863 , only 7 and 8 percent of the awards went to hand-woven products. But 1864 revealed a resurgence of woven textiles when they won 32 percent, or almost one-third, of the household manufacture awards. Through the rest of the 1860s, however, fewer and fewer awards went to woven goods. After the 1870 fair, awards and premiums given for woven products comprised less than 10 percent of all awards for "household goods." Awards to other types of textiles increased with a shift in interest to other hand processes and "fancy" rather than "staple" goods. Through the 1870s, 1880s, and 1890s, woven textiles were a very small fraction of the knitted, embroidered, quilted, crocheted, tatted, and sewn fair entries. ${ }^{41}$

40. Riley, "Family Life," 47-50.

41. Report, ISAS, 1854-1899, passim. 
Because weaving was still present in some southeast Iowa counties in the 1860 s and 1870 s, Iowa histories which present it as a home process for only frontier-log-cabin pioneers are inaccurate. Six counties in southeast Iowa were no longer a frontier in 1850, as measured by population density. By 1860 the rest of the region, with the exception of Iowa County, was no longer a frontier area. The use of log cabins also may not even have lasted through the frontier stages in southeast Iowa. Families were most liable to live in log cabins for two to three years in Iowa, only long enough to save money or obtain materials to build a larger three-to-four room house. Histories that deal with hand weaving only in relation to log cabins and an economically bleak frontier are thus in error. ${ }^{42}$

Iowans continued hand weaving despite the general availability of commercial cloth in many counties. Other considerations apart from necessity influenced the amount of home weaving done in southeast Iowa. Some home weavers sold their hand products to neighbors and within their local communities, and may have used hand-woven cloth to barter in exchange for other goods or needed services. In addition, an Iowa settler could use the skills required to produce textiles and clothing to help overcome times of economic necessity. Weavers could produce goods instead of purchasing them when personal finances prohibited store purchases, during economic depressions within the state, and during times such as the Civil War when specific goods were scarce and expensive. Many Iowans continued to weave into the twentieth century as a creative outlet or to perpetuate pride in a heritage that valued hand skills. Whatever its motivation, home weaving was a skill that not only gave the weaver personal satisfaction but also enabled a family to be more self-sufficient by fulfilling its basic needs for textiles and clothing.

42. The authors' definition of frontier is based on Michael Conzen's, as an area with two to fifteen persons per square mile. See "Local Migration Systems in 19th Century Iowa," Geographic Review 64 (July 1974), 339-361. Christie Dailey discussed the brevity of log cabin living on the Iowa frontier in "Women's Roles: Now and Then," an unpublished speech given at Iowa State University, Ames in 1982. See also Riley, Frontierswomen: The Iowa Experience, 29-55. 
Copyright of Annals of Iowa is the property of State of Iowa, by \& through the State Historical Society of Iowa and its content may not be copied or emailed to multiple sites or posted to a listserv without the copyright holder's express written permission. However, users may print, download, or email articles for individual use. 